\title{
INTERESTING FEATURES OF RADAR IMAGERY OF ICE- COVERED NORTH SLOPE LAKES
}

\author{
By W. F. Weeks, P. Sellmann \\ (U.S. Army Cold Regions Research and Engineering Laboratory, Hanover, New \\ Hampshire 03755, U.S.A.) \\ and W. J. Campbell \\ (U.S. Geological Survey, University of Puget Sound, Tacoma, Washington 98416, U.S.A.)
}

\begin{abstract}
Side-looking airborne radar (SLAR) imagery obtained in April-May 1974 from the North Slope of Alaska between Barrow and Harrison Bay indicates that tundra lakes can be separated into two classes based on the strength of the radar returns. Correlations between the areal patterns of the returns, limited ground observations on lake depths and water compositions, and information obtained from LANDSAT imagery strongly suggest that areas of fresh-water lakes giving weak returns are frozen completely to the bottom while areas giving strong returns are not. This is a reasonable interpretation inasmuch as the reflection coefficient associated with the high-dielectric-contrast ice-water interface would be roughly twelve times that associated with the low-contrast ice-soil interface. Brackish lakes also give weak returns even when they are not completely frozen. This is the result of the brine present in the lower portion of the ice cover limiting the penetration of the X-band radiation into the ice. The ability to separate tundra lakes rapidly and easily into these two classes via SLAR should be useful in understanding a wide variety of problems.

RÉsumÉ. Traits interessants de l'image radar des lacs englacés sur le North Slope. L'image au radar SLAR obtenue en avril-mai 1974 du North Slope de l'Alaska, entre Barrow et Harrison Bay, montre que les lacs de la toundra peuvent être classés en deux catégories sur la base de la puissance des images radar renvoyées. En rapprochant le développement en surface des images renvoyées, les rares observations directes sur la profondeur des lacs et la composition de l'eau, et les informations obtenues à partir des images des satellites LANDSAT, on est nettement conduit à la conclusion que les superficies des lacs d'eau douce donnant de faibles images sont entièrement gelés jusqu'au fond, tandis que les zones donnant des images puissantes ne le sont pas. Ceci est une interprétation raisonnable, d'autant plus que le coefficient de réflection associé au fort contraste diélectrique de l'interface eau-glace, devrait être environ 12 fois plus fort que celui associé au faible contraste de l'interface glace-sol. Les lacs saumâtres donnent aussi des images faibles, même lorsqu'ils ne sont pas complètement gelés. Ceci provient de la présence d'une saumure à la partie inférieure de la couverture de glace, limitant la pénération de la radiation des bandes X à l'intérieur de la glace. La possibilité de distinguer rapidement et facilement les deux classes de lacs de toundra grâce au SLAR devrait être utile pour la compréhension d'une grande variété de problèmes.
\end{abstract}

Zusammenfassung. Interessante Erscheinungen in den Radar-Bildern der eisbedeckten North-Slope-Seen. Bilder, aufgenommen mit Seitwärts-Radar im April und Mai 1974 über dem North Slope von Alaska zwischen Barrow und Harrison Bay, zeigen, dass die Tundra-Seen auf Grund der Stärke des Radar-Echos in zwei Klassen einzuteilen sind. Korrelationen zwischen der Gebietsverteilung der Echos, begrenzte Beobachtungen der See und Informationen aus LANDSAT-Bildern lassen mit hoher Wahrscheinlichkeit vermuten, dass Gebiete von Süsswasserseen, die nur schwache Echos geben, vollständig bis zum Grund gefroren sind, während dies für Gebiete mit starken Echos nicht gilt. Dies erscheint als vernünftige Deutung insofern, als der Reflexionskoeffizient für die Grenzfläche zwischen Eis und Wasser infolge des hohen dielektrischen Kontrastes etwa 12-mal grösser sein sollte als der für die Grenzfläche zwischen Eis und Boden mit ihrem niedrigen Kontrast. Salzwasserseen geben schwache Echos auch dann, wenn sie nicht völlig gefroren sind. Dies ist die Folge der Salzlauge, die im unteren Bereich der Eisdecke vorhanden ist und das Eindringen der Strahlung im X-Band in das Eis begrenzt. Die Möglichkeit zur schnellen und leichten Unterscheidung der Tundra-Seen in diese beiden Klassen mit Seitwärts-Radar sollte für das Verständnis mannigfaltiger Probleme von Nutzen sein.

\section{INTRODUGTION}

Between 25 April and 3 May 1974 a series of ten side-looking airborne radar (SLAR) flights were made along the coast of the North Slope of Alaska between Icy Cape and Prudhoe Bay. The SLAR used was a Motorola APS-94-XEI (X-band) system that was operated in the real aperture mode aboard a Mohawk aircraft of the U.S. Geological Survey. Most of the imagery was obtained at speeds and altitudes of approximately $82 \mathrm{~m} / \mathrm{s}$ ( $160 \mathrm{knots}$ ) and $\mathrm{I} 830 \mathrm{~m}$ (6 ooo feet) respectively. The radar system imaged swaths $25 \mathrm{~km}$ wide on both sides of the aircraft that were separated by a blind spot $10 \mathrm{~km}$ wide located beneath the aircraft. The 
resolution (horizontal) of the system was believed to be approximately $25 \mathrm{~m}$ in the near-range of the image changing to $150 \mathrm{~m}$ in the far-range. The purpose of the missions, which were part of a joint U.S. Geological Survey-U.S. Army Cold Regions Research and Engineering Laboratory project, was to investigate the characteristics of the near-shore pack and fast ice via the use of sequential SLAR flights.

During these flights, several passes were made over the lakes and tundra of the North Slope in the region between Barrow and Lonely where the flights would turn toward the north and proceed out over the Arctic pack. An index map of the region showing the location of the SLAR images presented in this paper, the complete area that was imaged, and the names of a number of geographic features is shown in Figure I. A composite SLAR mosaic of the complete area imaged can be found in Sellmann and others (1975[b]). In the present report we will only show details of features of interest. On the first of these flights, the SLAR image of the coastal plain was observed to present a rather uniform and uninteresting radar pattern in contrast to the intense variations in return, corresponding to changes in the roughness of the ice surface, observed over the sea ice. Therefore no particular effort was made to obtain imagery from the land areas.

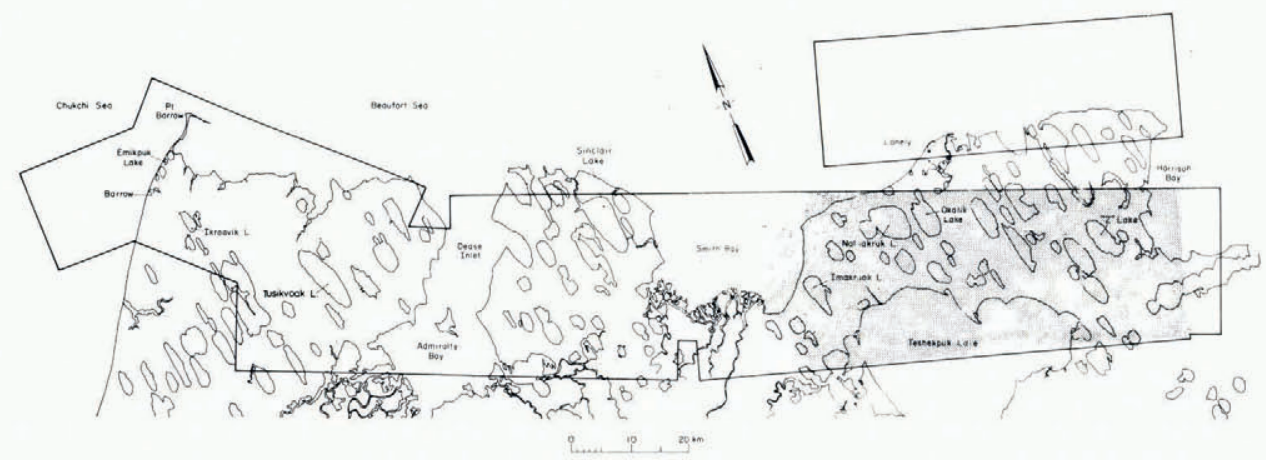

Fig. 1. Map of the Point Barrow-Harrison Bay area of the north coast of Alaska. The location of the SLAR image presented in Figure 2 is indicated by the shaded area. The complete area imaged is enclosed by solid lines (the complete SLAR mosaic is printed in Sellmann and others, $1975[b])$.

However toward the end of the series of flights, it was noted that setting changes in the radar background and brightness controls that were made to best define sea-ice features of interest, had also resulted in imagery in which the numerous elongated lakes that so characterize the North Slope were clearly shown. Based on the radar returns, the lakes could be separated into two different classes; those giving strong (bright) returns and those giving weak (dark) returns. This note discusses these differences in radar return, suggests two causes, and describes possible uses of the "effect".

\section{Observations}

The lakes discussed here are a unique feature of the Alaskan coastal-plain province and make up more than $40 \%$ of the surface area in some locations (Sellmann and others, 1975[a]). The striking orientation of their long axes as well as their characteristically shallow depths are produced by a unique thaw process that occurs in the ice-rich sediments combined with a control over the differential erosion rates within the lake basin that is related to the dominant wind direction (Carson and Hussey, 1962). Because of the rapid lake development and migration in this region, thaw lakes are considered the primary mechanism involved in modifying the landscape (Britton, 1967). The processes that cause the lakes to elongate and 
become highly oriented only take place during the summer after the ice cover has started to melt. During the winter, ice covers develop on these lakes with maximum ice thicknesses commonly reaching $2 \mathrm{~m}$. In areas where the snow pack is thin, ice thicknesses of up to $2.3 \mathrm{~m}$ may be encountered. Many of the shallower lakes are frozen completely to the bottom by the time that the ice cover reaches its maximum thickness (Brewer, 1958). The deeper lakes only freeze to the bottom around their shallow margins and not in the central parts of the lake basins.

The differences in radar back-scatter from the lakes can readily be noted in Figure 2 which shows the area between Smith and Harrison Bays. The two images which make up the composite were made on east-to-west flights between Lonely and Barrow (i.e. the aircraft was always north of the image). This can be discerned from the loss of detail in the image as one moves towards the south increasing both the distance between the object imaged and the aircraft and the angle of incidence between the radar beam and the Earth's surface. The difference between the stronger (bright-image) back-scatter from Naluakruk (marked I in Fig. 2), Okalik (2), Teshekpuk (3) and numerous other unnamed lakes as opposed to the weaker (dark-image) back-scatter shown by Imakruak (4) and unnamed lakes (5) and (6) is quite striking. Note also that some lake basins have pronounced low-return (dark) margins and high-return (bright) central portions: for instance Naluakruk Lake which has such a dark margin appears on the radar image as two separate (bright) lakes that are completely enclosed by the low-return area. Another lake (marked with a Z in Fig. 2) showing a pronounced dark rim can be found just west of Harrison Bay. Note the lack of correspondence between the

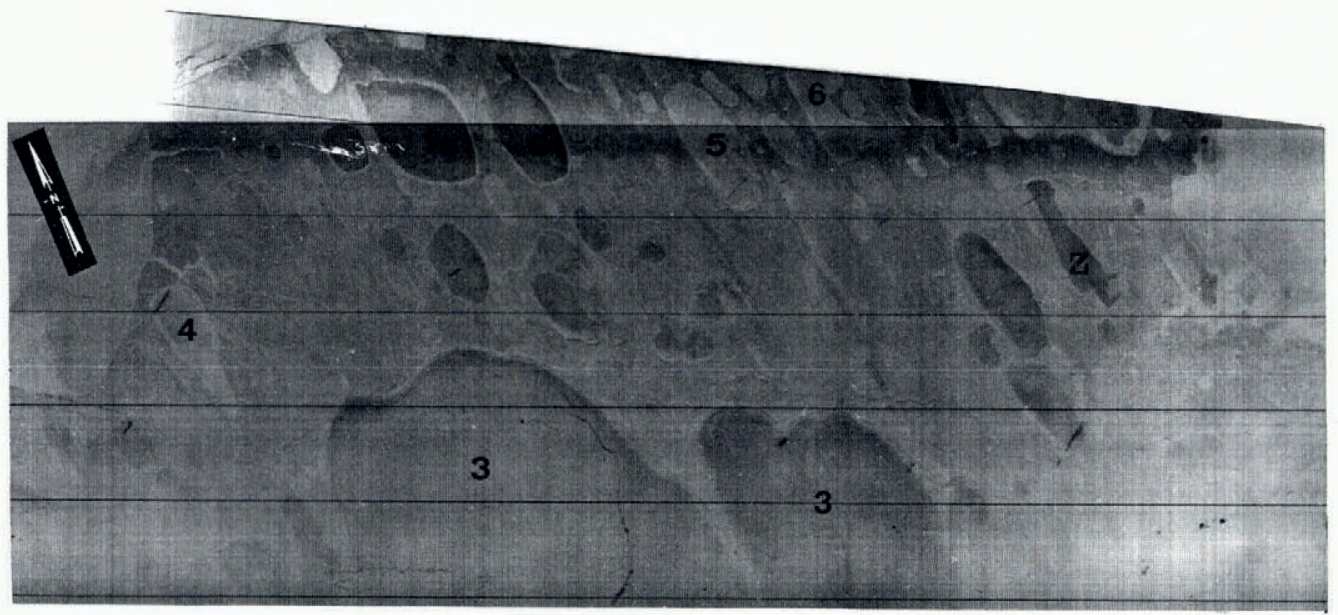

Fig. 2. SLAR mosaic of an area of the North Slope of Alaska between Smith and Harrison Bays (see Fig. I). The light lines on the images are spaced at $5 \mathrm{~km}$ intercals. Specific identified features are:

1. Valuakruk Lake.

2. Okalik Lake.

3. Teshekpuk Lake.

4. Imakruak Lake.

5-6. Unnamed lakes showing a low radar return.

z. Ennamed lake showing a shallow margin and a deep central portion. 
lake boundary as indicated by the high-return area and the lake boundary as indicated on the map. Numerous other examples can be found by closely examining Figure 2 and comparing it with Figure I.

The strongest radar returns in the area of the North Slope that was imaged (excluding the strong returns from highly deformed areas of sea ice) were those associated with the activities of man (the buildings at Barrow and Lonely). Note also the strong linear returns that show on the surfaces of a number of lakes such as Imakruak (4); these are caused by snow-banks along the sides of temporary winter runways established on the lake ice and used to resupply geophysical field parties. Of particular interest is the runway on the lake marked $\mathrm{Z}$ in that it is sited over both the inner high-return portion of the lake and the outer low-return portion.

\section{INTERPRETATION}

The differences in radar back-scatter from most of the tundra lakes indicate whether or not the lake is frozen completely to the bottom at the location in question. This interpretation is based on several different pieces of information. First we know from direct observations that many of the low-return lakes in the vicinity of Barrow do freeze completely to the bottom and also that most of the lakes on this part of the North Slope are quite shallow (Holmquist, I 975 ; U.S. Dept. of the Navy, 1975). Second, the fresh-water lakes which are known to be deeper than the only observed ice-thickness measured at the time of the overflight $(2.0 \mathrm{~m}$ on Ikroavik Lake) all give high radar returns. These lakes include Tusikvoak, Naluakruk, Teshekpuk and Ikroavik (Holmquist, I975; U.S. Dept. of the Navy, 1975). Finally a recent study of the dissipation of the winter's ice cover on the lake basins of the coastal plain, based on the use of sequential LANDSAT imagery (Sellmann and others, 1975[a]) has shown that lake areas retaining their ice cover longest are those which have not been frozen to the bottom.

Figure 3 shows a LANDSAT image (MSS band 7, 0.8-1. I $\mu \mathrm{m}$ ) of the present study area obtained on 3 July 1973. When this early summer image is compared to the late-winter SLAR image, the tone contrasts shown on SLAR compare directly with the shape of the remaining ice masses as shown by LANDSAT with the "dark" low-return lake areas corresponding to areas that are ice free. The agreement between the two types of images is far too good to be coincidental. For instance in Figures 2 and 3 compare the SLAR and LANDSAT images of lake $\mathrm{Z}$ which has a deeper central basin which has remained ice covered while the shallow shelf around the margins of the lake (which presumably froze completely to the bottom) is ice free. Similar agreement can be seen when a comparison is made between the shallow areas in the Teshekpuk Lake basin.

At the present time we cannot positively identify the physical cause (or causes) for the observed difference in radar back-scatter other than to point out the correlation with lakes that do or do not freeze to the bottom. We can, however, discuss several possible "effects" which could produce the observed differences. These effects can be grouped into four classes related to differences in ice and snow surface properties, thermal contrasts, ice thickness, and ice bottom interface conditions:

a. Surface roughness. Changes in the nature of the surface roughness of the ice (brash ice, finger rafting, pressure ridging) or the snow (sastrugi) would cause pronounced differences in the radar back-scatter coefficient with the brightest returns being produced by the roughest surfaces. However we can see no reason why there should be a correlation between the roughness of the ice or snow surface and whether or not a lake is frozen to its bed. This is not to say that the surface roughness of all the lakes is identical. (In fact, visual tonal contrasts corresponding to surface roughness variations have been observed in the early winter on lakes that are not yet snow-covered and are similar to those studied here (personal communication from A. Kovacs).) However, the most apparent pattern of these tones corresponds to that expected to result from slush blowing to one side of the lake during the initial formation of 


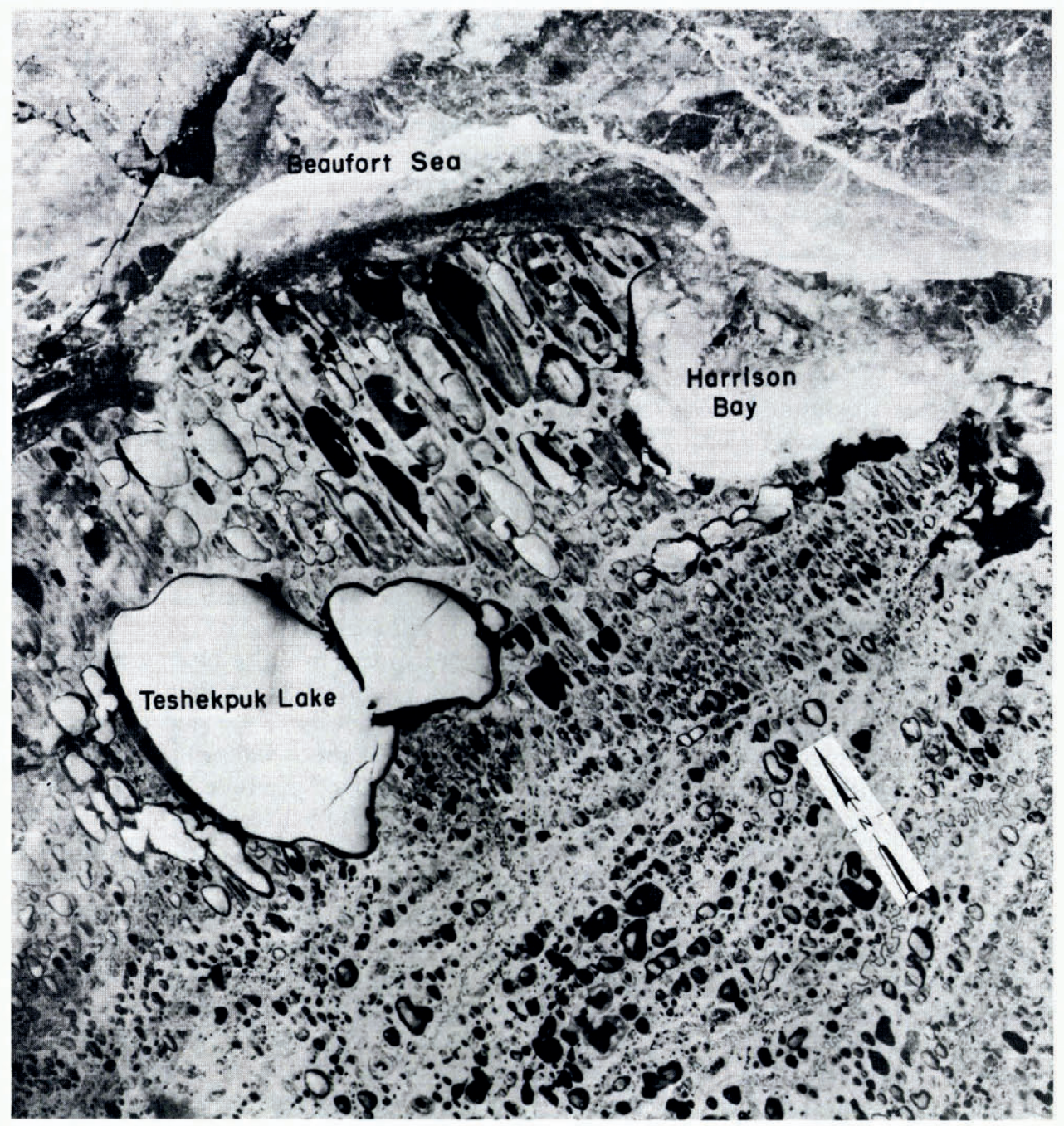

Fig. 3. LANDSAT-I image of the Teshekpuk Lake region of the North Slope taken on 3 July 1973 (MSS band-7, o.8-I.I $\mu \mathrm{m}$,

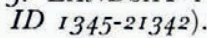

the ice cover with the remainder of the lake being covered with a smooth ice sheet which formed after the wind subsided. There is, at present, no reason to believe that these tonal changes correspond to or produce the observed SLAR variations. In addition we would expect that the radar patterns produced by surface-roughness elements on lake ice would be similar to those produced by equivalent features on sea ice. This is not the case inasmuch as the bright returns from lake ice are quite uniform relative to the bright returns from sea ice which are obviously produced by ridges and sea-ice rubble. Therefore we doubt that the observed difference in radar return is the result of variations in surface roughness.

b. Thermal contrasts. On lakes that freeze completely to the bottom, the temperature at the lake-ice-snow interface would be expected to be colder than for lakes that are not frozen 
to the bottom. This would result in a more pronounced temperature gradient in the snow pack over the unfrozen lakes and could cause associated changes in the snow-pack characteristics. These changes, such as extensive grain growth and depth-hoar formation, could conceivably result in an increase in the back-scatter coefficient over the unfrozen lakes. However this is probably not the cause of the observed change in back-scatter inasmuch as X-band SLAR tends not to show reflections from snow, showing instead the stronger reflections from the surfaces beneath the snow (Page and Ramseier, 1975). Also recent studies (Benson and others, 1975) of snow-pack characteristics on the North Slope show that extensive depth-hoar formation and grain growth is the rule even in the snow pack on the land surface. Finally if these observed changes were the result of different snow characteristics, one would expect to see some evidence of the east-west oriented drifts that are commonly formed on North Slope lakes associated with the prevailing wind directions (Benson and others, 1975).

c. Ice thickness differences. As the ice cover becomes thicker there is the possibility of increased back-scatter from additional scattering elements such as bubble layers that are located in the additional thickness of ice. This is an unlikely explanation inasmuch as it would be expected to produce a range of back-scatter coefficients (the ice in the areas that are frozen to the bottom is not all of the same thickness) while, in fact, the low-return areas are all quite similar.

d. Ice-bottom interface conditions. Areas of lakes that are not frozen completely to the bottom comprise in vertical profile (snow-ice-water-soil) systems as compared to (snow-ice-soil) systems on the completely frozen lakes. The boundary between these two types of systems on any given lake is well defined corresponding to the grounding line of the base of the ice cover. The dielectric constants at X-band frequencies are quite similar for ice and frozen soil (ice: $\epsilon^{\prime}=3.12$ (Vant and others, 1974); frozen ice-rich silt and clay: $\epsilon^{\prime}=3-6$ (Hoekstra and Delaney, 1974)). The dielectric constant of water at $0^{\circ} \mathrm{C}$ is much larger $\left(\epsilon^{\prime}=46\right.$, Hasted, 1973). This large dielectric contrast at the ice-water interface produces a large reflection coefficient causing an increase in the amount of back-scatter to approximately twelve times the value that would be expected from an ice-soil interface (Lorrain and Corson, 1970, p. 519).

This leaves the following question: is there sufficient penetration of the lake ice cover by the radar so that the difference in reflection coefficient at the base of the ice cover will be apparent? There are three points that suggest that answer to this is yes. First, lake ice is a low-loss dielectric (if a $\tan \delta$ of $0.00 \mathrm{I}$ is assumed (Vant and others, I 974), the attenuation is I. $6 \mathrm{~dB} / \mathrm{m}$ corresponding to an attenuation distance of $5.4 \mathrm{~m}$ (the distance that it takes the field strength to decay to $\mathrm{I} / \mathrm{e}=0.368$ of its original value $)$ ). Second, there is strong evidence from other investigators suggesting that significant radar returns can be obtained from the bottom surface of lake-ice covers. For instance, Jirberg and others (1974) have found that some high SLAR returns on imagery of the Lake Erie ice cover can be correlated with the presence of rough ice-water interfaces. The ice on Lake Erie is, of course, much thinner than the ice on the North Slope lakes. Finally, as reported in the present paper, the correspondence between strong SLAR returns and lakes or areas of lakes that are deeper than the thickness of the ice cover is simply too good to be coincidental. Similar and perhaps even more striking examples of such correspondence can be observed in SLAR imagery of the ice-covered river channels in the McKenzie Delta region as reported by Campbell and others (1975, see their fig. 16). The meanders of the deep main channel to the outside of bends in the river are clearly shown by the high radar returns.

One qualification should be attached to the previous suggestion that weak radar returns indicate lakes that are frozen completely to the bottom. Imikpuk Lake, located between Barrow Village and the Naval Arctic Research Laboratory (NARL), gives a weak return suggesting that it is frozen to the bottom. It is, however, known that this lake does not freeze completely to the bottom since its maximum depth is $2.8 \mathrm{~m}$ (Brewer, 1958) and it is used as a water supply for NARL. It is also known that toward the end of the ice-growth season the 
small amount of water remaining in the lake becomes quite saline because of the concentration in it of the impurities rejected by the ice and contact with brackish bottom sediments. In early April I 975 the salinity of the water being taken from Imikpuk Lake was $5.2 \%$. Ice forming from this water more closely resembles sea ice than lake ice in that the liquid brine present in the ice limits the penetration of X-band radiation. Such brackish ice would be expected to have an attenuation of between $5^{\circ}$ and ${ }^{1} 5^{\circ} \mathrm{dB} / \mathrm{m}$ depending on the temperature (M. R. Vant, unpublished results). This explanation can, however, only be invoked to explain the low returns from lakes right on the coast which were known to have been flooded with sea-water during the 3 October 1963 storm surge (Imikpuk Lake), to have direct connection to the ocean allowing the encroachment of sea-water (the lakes on either side of Imikpuk and Sinclair Lake located between Dease Inlet and Smith Bay), or to be brackish because of contact with saline sediments combined with sufficient freeze-concentration to cause a sea-ice substructure to become stable in the lower portion of the ice cover.

\section{Conclusion}

Whatever the reason, the ability to differentiate via SLAR between lakes that are fresh and not frozen to their bottoms and lakes that are either frozen to their bottoms and/or brackish is of considerable economic, scientific and engineering interest. One series of flights made at the time when the lake-ice covers are at their maximum thickness would allow valuable information to be obtained on whether or not a given lake (I) was suitable as a year-round source of water, (2) should be considered for possible fishing or for stocking with fish, or (3) should be considered as a site where permafrost may be deeply thawed due to the thermal effect of the year-round presence of a water body. Clearly a series of spring SLAR flights over the coastal plain with instrument settings optimized to bring out the details of the lakes would be extremely worthwhile. To derive the optimum benefits the flights should be coupled with a field study to establish the degree of correlation with water depth, water chemistry, ice thickness and ice surface characteristics, as well. as to establish conclusively the mechanism responsible for the SLAR contrasts. It should also be noted that the Synthetic Aperture Radar (SAR) system that will be carried by the satellite SEASAT-A which is scheduled for launch in 1978 will produce radar imagery that will allow the large areas of lakes in Alaska and northern Canada to be examined in a sequential manner during the icegrowth season.

\section{Agknowledgements}

The authors would like to thank Herbert Skibitzke, Marylou Brown, Patrick Walters and Ruby Sheldon of the U.S. Geological Survey Water Resources Division Remote Sensing Facility for their support in organizing this program and in operating the equipment. The authors would also like to thank the Director and staff of the Naval Arctic Research Laboratory for the support and hospitality they provided at Barrow. Dr Pieter Hoekstra, Dr Jerry Brown and Steven Arcone advised the authors on several technical problems related to radar back-scatter and Arctic lakes and reviewed an early version of this report.

The research was supported by the Arctic Program, Office of Naval Research; the Water Resources Division, U.S. Geological Survey; and the Research and Development Office of the Corps of Engineers, U.S. Army.

MS. received ${ }_{13}$ February 1976 and in revised form 29 June 1976 


\section{REFERENGES}

Benson, C. S., and others. 1975. Observations on the seasonal snow cover and radiation climate at Prudhoe Bay, Alaska during 1972 , by C. [S.] Benson, B. Holmgren, R. Timmer, G. Weller and S. Parrish. (In Brown, J., ed. Ecological investigations of the tundra biome in the Prudhoe Bay region, Alaska. Fairbanks, Alaska, University of Alaska, p. 13-50. (Biological Papers of the University of Alaska. Special Report No. 2.)).

Brewer, M. C. 1958. The thermal regime of an Arctic lake. Transactions. American Geophysical Union, Vol. 39, No. 2 , p. $278-84$.

Britton, M. E. 1967 . Vegetation of the Arctic tundra. (In Hansen, H. P., ed. Arctic biology. Corvallis, Oregon, Oregon State University Press, p. 67-130.)

Campbell, W. J., and others. 1975. An integrated approach to the remote sensing of floating ice, by W. J. Campbell, R. O. Ramseier, W. F. Weeks and P. Gloersen. Proceedings of the third Canadian Symposium on Remote Sensing, Edmonton, Alberta, 22-24 September 1975, p. 39-72.

Carson, C. E., and Hussey, K. M. 1962. Oriented lakes of Arctic Alaska. Journal of Geology, Vol. 7o, No. 4, p. 4I 7-39.

Hasted, J. B. 1973. Aqueous dielectrics. London, Chapman and Hall.

Hoekstra, P., and Delaney, A. 1974. Dielectric properties of soils at UHF and microwave frequencies. Journal of Geophysical Research, Vol. 79, No. 1 1, p. 1699-1 708.

Holmquist, C. 1975. Lakes of northern Alaska and northwestern Canada and their invertebrate fauna. Zoologische Jahrbücher. Abteilung für Systematik, Okology und Geographie der Tiere, Bd. 102, p. 333-484.

Jirberg, R. J., and others. 1974. Application of SLAR for monitoring Great Lakes total ice cover, [by] R. J. Jirberg, R. J. Schertler, R. T. Gedney, H. Mark. (In Santeford, H. S., and Smith, J. L., comp. Advanced concepts and techniques in the study of snow and ice resources. Washington, D.C., National Academy of Sciences, p. $402-$ II.)

Lorrain, P., and Corson, D. R. 1970. Electromagnetic fields and waves. San Francisco, W. H. Freeman and Co.

Page, D. F., and Ramseier, R. O. 1975. Application of radar techniques to ice and snow studies. Journal of Glaciology, Vol. I 5, No. 73, p. I 7 I-91.

Sellmann, P. V., and others. I975[a]. The classification and geomorphic implications of thaw lakes found in Arctic Alaska, by P. V. Sellmann, J. Brown, R. I. Lewellen, H. McKim and C. Merry. U.S. Cold Regions Research and Engineering Laboratory. Research Report 344.

Sellmann, P. V., and others. I975[b]. Use of side-looking airborne radar to determine lake depth on the Alaskan North Slope, by P. V. Sellmann, W. F. Weeks and W. J. Campbell. U.S. Cold Regions Research and Engineering Laboratory. Special Report 230.

U.S. Dept. of the Navy. 1975. Final environmental impact statement, continuing exploration and evaluation of NPR-4, Alaska (Zone A). Washington, D.C., Dept. of the Navy, Naval Petroleum and Oil Shale Reserves.

Vant, M. R., and others. 1974. Dielectric properties of fresh and sea ice at 10 and $35 \mathrm{GHz}$, [by] M. R. Vant, R. B. Gray, R. O. Ramseier, V. Makios. Journal of Applied Physics, Vol. 45, No. 11, p. $4712-17$. 